\title{
Nature and Properties of a Cytolytic Agent Produced by Bacillus subtilis
}

\author{
By A. W. BER NHEIMER AND LOIS S. AVIGAD \\ Department of Microbiology, New York University School of Medicine, \\ New York, N.Y. Ioor6, U.S.A. \\ (Accepted for publication 23 February 1970)
}

\begin{abstract}
SUMMARY
The substance responsible for lysis of erythrocytes by cultures of Bacillus subtilis, designated subtilysin, was purified. It contained a peptide of leucine, aspartic acid, glutamic acid and valine and probably a lipid. Subtilysin was activated by $\mathrm{Mg}^{2+}, \mathrm{Mn}^{2+}$ and $\mathrm{Ca}^{2+}$. The rate of haemolysis was abruptly increased by chilling the reaction mixture. Haemolysis was inhibited by normal sera; the most inhibitory serum fractions contained $\alpha-$ and $\beta$-globulins. Haemolysis was inhibited by low concentrations of phosphatidylcholine, phosphatidylinositol, phosphatidic acid and sphingomyelin. Subtilysin possessed antibiotic properties and lysed protoplasts and spheroplasts derived from several bacterial species; subtilysin was identical with surfactin, a peptidelipid from $B$. subtilis cultures that inhibits fibrin clot formation. Kakinuma and co-workers found surfactin to be a heptapeptide having an $\mathrm{N}$-terminal glutamic acid in amide linkage with the carboxyl group of 3hydroxy-I3-methyl-tetradecanoic acid. Surfactin (subtilysin) possesses some properties in common with two other cytolytic agents of bacterial origin, namely, staphylococcal $\delta$-toxin and streptolysin $\mathrm{S}$.
\end{abstract}

\section{INTRODUCTION}

In an earlier study a series of aerobic sporogenic bacilli was surveyed for production of haemolysin active against rabbit erythrocytes (Bernheimer \& Grushoff, 1967). Among the species examined, broth cultures of Bacillus cereus, B. alvei and B. laterosporus were found to contain relatively potent lysins that were activated by SHcompounds and that belonged to the group of oxygen-labile haemolysins of which streptolysin $O$ is the prototype (Bernheimer, 1970). B. subtilis produced a haemolysin which appeared to differ from these. What can be assumed to be the same lysin of B. subtilis was studied by Büsing (1950) and later by Williams (1957), who found the active moiety had the solubility properties of an organic acid. To establish more exactly its nature and properties, we have re-investigated this lytic agent; it is provisionally designated 'subtilysin'.

\section{METHODS}

Organism. Bacillus subtilis QMB 1228 was supplied by Dr H. S. Levinson.

Reagents. Phosphatidylcholine and diphosphatidylglycerol were bought from Sylvana Co. (Milburn, N.J.); phosphatidylserine, phosphatidylethanolamine, sphingomyelin and cerebrosides from Applied Science Laboratories, Inc. (State College, Pa.); phosphatidic acid from General Biochemicals (Chagrin Falls, Ohio); phosphatidyl- 
inositol and serum fractions from Nutritional Biochemicals Corp. (Cleveland, Ohio); cholesterol from Matheson, Coleman and Bell (East Rutherford, N.J.).

Measurement of haemolytic activity. In the early part of the investigation, capacity of subtilysin to lyse washed rabbit erythrocytes was measured as for staphylococcal $\alpha$-toxin (Bernheimer \& Schwartz, 1963) but with 0.I \% (w/v) gelatin instead of bovine serum albumin. This method utilized phosphate-buffered saline solution and an incubation period of $30 \mathrm{~min}$. at $37^{\circ}$; later, the method was altered by substituting for phosphate buffer, tris buffer $+\mathrm{Mg}$ and by incubating the mixtures of lysin and cells for $30 \mathrm{~min}$. at $37^{\circ}$ followed by $30 \mathrm{~min}$. in an ice-bath. These changes resulted in titres about three times as great as those obtained under the conditions first used. In the method finally adopted, test preparations were diluted in $0.84 \%(\mathrm{w} / \mathrm{v}) \mathrm{NaCl}$ (buffered at $\mathrm{pH} 7 \cdot 2$ ) with $0.0 \mathrm{I} \mathrm{M}$-tris containing $0 . \mathrm{I} \%(\mathrm{w} / \mathrm{v})$ gelatin $+0.0 \mathrm{I} \mathrm{M}-\mathrm{MgCl}_{2}$. To I ml. of each of a series of dilutions increasing in about $30 \%$ steps was added I ml. of a twicewashed suspension of rabbit red blood cells. The medium in which the cells were washed and suspended was $0.84 \%(\mathrm{w} / \mathrm{v}) \mathrm{NaCl}$ buffered at $\mathrm{pH} 7.2$ with $0.0 \mathrm{I}$ M-tris. The concentration of the red cell suspension (about $0.7 \%, \mathrm{v} / \mathrm{v}$ ) was adjusted so that a sample, after lysis with saponin and addition of an equal volume of diluent, gave a spectrophotometric (Zeiss) extinction of 0.8 with light of $545 \mathrm{~nm}$. and a light path of $\mathrm{I} \mathrm{cm}$. The mixtures of subtilysin dilutions and red blood cells were put in a $37^{\circ}$ water-bath for $30 \mathrm{~min}$., removed to an ice-bath for $30 \mathrm{~min}$. and then centrifuged briefly. The colour of the haemoglobin in the supernatant fluids was compared visually with standard haemoglobin solutions, and the dilution haemolysing $50 \%$ of the red cells in the suspension determined by interpolation. A unit of subtilysin is defined as that amount which liberates half the haemoglobin in the test red cell suspension under the conditions stated.

Production of subtilysin. In preliminary experiments the quantity of subtilysin produced in cultures utilizing a variety of media was estimated by titrating culture supernatant fluids for haemolytic activity; stationary and shaking cultures were used. The casein basal medium of Knight \& Proom (1950) supplemented with a small amount of yeast extract gave satisfactory titres of subtilysin. Io g. of Casamino acids (Difco Laboratories, Detroit, Michigan), $5 \mathrm{~g} . \mathrm{KH}_{2} \mathrm{PO}_{4}, \mathrm{I} \mathrm{g}$. NaCl, $100 \mathrm{mg}$. tryptophan and Io $\mathrm{mg}$. cystine were dissolved in a litre of water, and the mixture adjusted to $\mathrm{pH} 7 \cdot 0$, the medium brought to a boil, filtered through paper, and distributed in $50 \mathrm{ml}$. amounts/ $250 \mathrm{ml}$. Erlenmeyer flask. Sterilization was at $\mathrm{I} 23^{\circ}$ for $20 \mathrm{~min}$. To each flask was added $0.13 \mathrm{ml} .20 \%$ (w/v) solution of yeast extract (Difco Laboratories, Detroit, Michigan). Growth and subtilysin formation in this medium are illustrated by the data of Table I derived from flasks which received an inoculum of $5 \mathrm{ml}$. and incubated at $37^{\circ}$ in a shaking water-bath. Within limits of error of measurement the haemolytic activity paralleled the degree of growth. Addition to the medium of glucose, sodium ribonuclease or serum did not yield significantly higher titres.

For routine production of subtilysin a seed culture was prepared by adding a loopful of growth from an agar plate to $50 \mathrm{ml}$. medium and incubating in a shaking water-bath to an extinction of about $\mathrm{I} \cdot \mathrm{O}$ at $650 \mathrm{~nm}$. Eight flasks containing $50 \mathrm{ml}$. medium were each inoculated with $\mathrm{I} \mathrm{ml}$. of a $1 \mathrm{r}^{4}$ dilution of seed culture and incubated in a shaking water-bath at $37^{\circ}$ for $17 \mathrm{~h}$. Supernatant fluids of the cultures usually contained 20 to 40 subtilysin units $/ \mathrm{ml}$. 


\section{RESULTS}

\section{Purification of subtilysin}

Unless otherwise noted purification was at room temperature. The combined supernatant fluids from a series of cultures (stage $I$, Table 2) were concentrated seven- to tenfold by pervaporation through Cellophane sacks. The decrease in volume was accompanied by formation of a precipitate (stage 2) which was collected by centrifuga-

Table I. Growth of Bacillus subtilis and course of appearance of subtilysin

$\begin{array}{ccc}\begin{array}{c}\text { Time of } \\ \text { incubation } \\ \text { (hr) }\end{array} & \begin{array}{c}\text { Growth as } \\ \text { extinction at } \\ 650 \mathrm{~nm} .\end{array} & \begin{array}{c}\text { Subtilysin in culture } \\ \text { supernatant fluid* }\end{array} \\ 4 & 0.62 & 4 \\ 7 & 2 \cdot 1 & 13 \\ 16 & 3.5 & 18 \\ 24 & 5 \cdot 2 & 23\end{array}$

* Units of haemolytic activity/ml. obtained by titrations utilizing phosphate-buffered saline and incubation time of $30 \mathrm{~min}$.

Table 2. Purification and recovery of subtilysin

$\begin{array}{lccc}\text { Volume } & \begin{array}{c}\text { Total units } \\ \text { of subtilysin }\end{array} & \begin{array}{c}\text { Recovery of } \\ \text { activity } \\ (\%)\end{array} \\ \text { Stage I. Culture supernatant fluid } & 1,055 & 35,000 & 100 \\ \text { Stage 2. Precipitate from pervaporation } & 134 & 35,000 & 100 \\ \text { Stage 3. Acid precipitate } & 30 & 15,000 & 43 \\ \text { Stage 4. Salt precipitate } & 30 & 18,300 & 52 \\ \text { Stage 5. Dialysed and lyophilized } & - & 20,100 & 57 \\ \quad \text { product, 234 mg. } & & & \end{array}$

tion and which contained virtually all the subtilysin activity. The supernatant fluid, containing less than Io units of subtilysin/ml. was discarded. The precipitate was washed twice with $30 \mathrm{ml} .10 \%(\mathrm{w} / \mathrm{v}) \mathrm{NaCl}$ and then dissolved in $30 \mathrm{ml}$. distilled water. A small amount of insoluble material was removed by centrifugation, and the supernatant fluid was adjusted with $\mathrm{N}-\mathrm{HCl}$ to $\mathrm{pH} 4^{\circ}$. The precipitate which formed was washed twice with $30 \mathrm{ml}$. O.I N-acetate buffer $(\mathrm{pH} 4)$, and then suspended in $30 \mathrm{ml}$. $0.05 \mathrm{~N}$-tris ( $\mathrm{pH} 7.5$ ). Sufficient $\mathrm{NaOH}$ was added to the mixture to bring to slightly above neutral $\mathrm{pH}$ and solution was left to occur overnight in the cold (stage 3).

A small amount of insoluble material was removed by centrifugation, and solid $\mathrm{NaCl}$ was added to $10 \%(\mathrm{w} / \mathrm{v})$. After standing $60 \mathrm{~min}$. the mixture was centrifuged for Io $\mathrm{min}$. at $10,000 \mathrm{rev} / \mathrm{min}$. The opalescent supernatant fluid, which contained 50 units subtilysin/ml., was discarded. The precipitate was stirred with $30 \mathrm{ml} .0 .05 \mathrm{~N}$-tris ( $\mathrm{pH} 7 \cdot 5$ ) allowing several hours for solution to occur (stage 4). The solution was dialyzed at $4^{\circ}$ against two changes of distilled water ( $1800 \mathrm{ml}$.) over about $20 \mathrm{hr}$, and then freeze-dried. A white solid $(234 \mathrm{mg}$.) was obtained (stage 5). This product had a specific activity of 86 haemolytic units/mg. The specific activities of a series of such products varied from 55 to 95 haemolytic units/mg. Further purification was 
attempted by iso-electric focusing and by use of a Sephadex G-I00 column. Upon iso-electric focusing, subtilysin precipitated as it moved into the region $\mathrm{pH}_{4}$ to 5 ; in Sephadex no further increase in specific activity was achieved.

\section{Physical and chemical properties}

Subtilysin was soluble in slightly alkaline water, in ethanol, acetone and chloroform; it was precipitated from aqueous solution by $10 \% \mathrm{NaCl}(\mathrm{w} / \mathrm{v})$ or by acidification to $\mathrm{pH} 4$; it did not diffuse through Cellophane. Solutions retained their haemolytic activity at $100^{\circ}$ for $15 \mathrm{~min}$. at $\mathrm{pH} 8.2$ or 9.6 , but at $\mathrm{pH} 3.0$ two-thirds of the activity disappeared. The haemolytic activity of subtilysin was not affected by treatment with trypsin, papain or pronase. These properties suggested that the active material was of relatively large molecular size but was apparently not a protein.

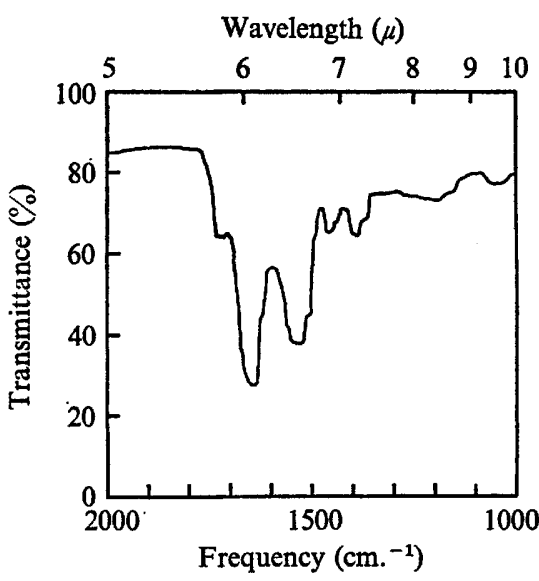

Fig. I

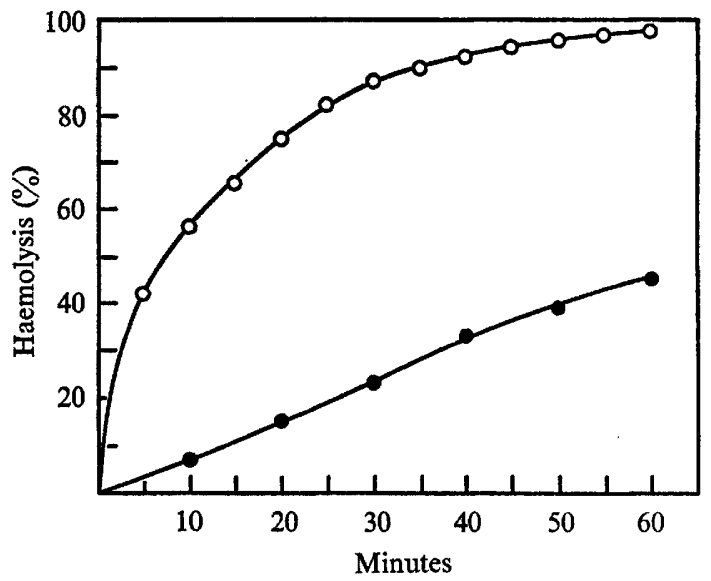

Fig. 2

Fig. I. Infrared spectrum of subtilysin.

Fig. 2. Course of haemolysis in presence of $0.005 \mathrm{M}-\mathrm{MgCl}_{2}$ (open circles) and in absence of added $\mathrm{Mg}^{2+}$ (solid circles).

A solution containing $7 \mathrm{mg}$. subtilysin/ml. $0.05 \mathrm{M}$-tris buffer $(\mathrm{pH} 7.5)$ appeared to be homogeneous in the analytical ultracentrifuge, giving a single peak having an $S_{20} \mathrm{w}$ of about I·2. Using a column of Sephadex G-IOO (superfine) equilibrated with $0.03 \mathrm{M}$ sodium borate buffer ( $\mathrm{pH} 8 \cdot 5$ ) containing $0.1 \mathrm{M}-\mathrm{KCl}$, and calibrated with bovine serum albumin, ovalbumin and cytochrome $c$, elution volumes plotted according to Andrews (I964) gave a molecular weight of about 50,000.

Subtilysin was estimated to contain $8.8 \%$ nitrogen (micro-Kjeldahl analysis), less than $0.3 \%$ phosphorous (Lohmann \& Jendrassik, I926) and less than I \% carbohydrate as glucose by the anthrone reaction (Colowick \& Kaplan, 1957). When assayed for protein by the method of Lowry, Rosebrough, Farr \& Randall (I95I) it gave a colour equivalent to $4 \%$ of that produced by an equal weight of ovalbumin. Subtilysin after hydrolysis for $22 \mathrm{hr}$ at $110^{\circ}$ in $6.5 \mathrm{~N}-\mathrm{HCl}$ yielded a ninhydrin colour equivalent to $75 \%$ of that given by an equal weight of ovalbumin.

Analysis for amino acids (Blackburn, I968) showed leucine, aspartic acid, glutamic acid and valine in molar ratio near 4:I:I:I. Infrared absorption $(\mathrm{KBr})$ yielded a 
spectrum (Fig. I) consistent with lipid as well as of a peptide. The presence of lipid could also account for the solubility properties, the nitrogen content and the low sedimentation coefficient in relation to molecular size as determined by gel filtration. The formula weight of subtilysin is 1036 ; therefore the material formed aggregates of large size. Consistent with this was a tendency for subtilysin to give solutions that were opalescent.

\section{Haemolysis and inhibition of haemolysis}

Divalent cations. The following experiment shows the effect of $\mathrm{MgCl}_{2}$ on haemolysis. $15 \mathrm{ml}$. tris-buffered saline $(0.84 \%, \mathrm{w} / \mathrm{v}, \mathrm{NaCl}$ at $\mathrm{pH} 7.2$ with $0.1 \mathrm{M}$-tris $)$ containing 35 haemolysin units was mixed with $15 \mathrm{ml} .0 \cdot 7 \%(\mathrm{v} / \mathrm{v})$ washed rabbit erythrocytes in tris-buffered saline; both solutions were pre-warmed to $37^{\circ}$; a similar mixture was prepared with $0.005 \mathrm{M}-\mathrm{MgCl}_{2}$ present. Samples were taken at intervals and immediately centrifuged, and the percentage haemolysis estimated from light absorption readings at $545 \mathrm{~nm}$. The results (Fig. 2) show that $\mathrm{Mg}$ substantially increased the rate of lysis. A similar effect was produced when $\mathrm{Ca}$ or $\mathrm{Mn}$ were substituted for $\mathrm{Mg}$.

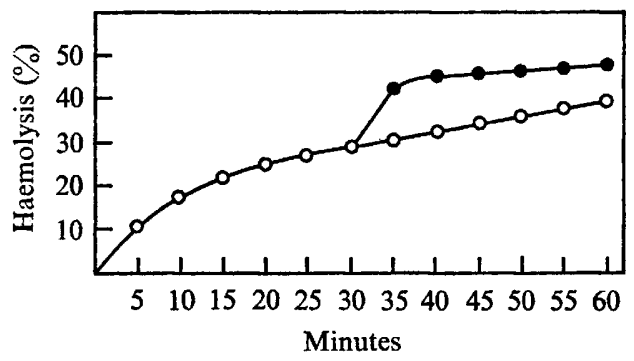

Fig. 3. Effect of chilling on course of haemolysis. Open circles: reaction mixture at $37^{\circ}$ throughout: solid circles: reaction mixture at $37^{\circ}$ for $30 \mathrm{~min}$. and then chilled.

'Hot-cold' effect. The experimental conditions were like those described, but the concentration of subtilysin was about two-thirds as great, and $0.005 \mathrm{M}-\mathrm{MgCl}_{2}$ was in each of two flasks of reaction mixture: one was at $37^{\circ}$ for the duration of the experiment: the other was at $37^{\circ}$ for $30 \mathrm{~min}$. and then chilled in an ice-bath. The results (Fig. 3) show that chilling increased abruptly the rate of lysis.

Source of erythrocytes. Assays of the haemolytic activity of a single preparation of subtilysin with erythrocytes from four different rabbits agreed within $10 \%$; the sensitivity of erythrocytes derived from man and guinea pig resembled that of rabbit cells. About four times as much subtilysin was required to produce $50 \%$ lysis of erythrocyte suspensions derived from calf, sheep and goat as for rabbit erythrocytes. The sensitivity of red cells from horse, pig, cat and chicken was less than that of rabbit cells but greater than that of cells from calf, sheep and goat.

Inhibition of haemolysis by serum and serum fractions. The capacity of serum to inhibit the haemolytic activity of subtilysin was assayed by mixing decreasing concentrations with a fixed amount ( 3 haemolysin units) of subtilysin, allowing the mixtures of $\mathrm{I} \mathrm{ml}$. each to stand for Io min. at $20^{\circ}$, and then adding $\mathrm{I} \mathrm{ml} .0 .7 \%(\mathrm{v} / \mathrm{v})$ washed rabbit red cells. After $30 \mathrm{~min}$. at $37^{\circ}$ followed by $30 \mathrm{~min}$. in an ice-bath, the mixtures were centrifuged briefly and the haemoglobin in the supernatant fluids estimated colorimetrically at $545 \mathrm{~nm}$. The tests were done in tris-buffered saline containing 
$0.005 \mathrm{M}-\mathrm{MgCl}_{2}$ and $0.05 \%$ gelatin; $50 \%$ haemolysis was used as the endpoint of the titrations. About $0.005 \mathrm{ml}$. normal serum, whether from man, rabbit, calf or horse, was required to inhibit 2 haemolysin units, i.e. two-thirds the test amount of subtilysin. Assay of several Cohn fractions of human serum showed that they inhibited haemolysis in order of decreasing effectiveness as follows: $\alpha$-globulin (fraction IV-I), $\beta$ lipoprotein (fraction III-0), $\alpha$-globulin (fraction IV-4) and albumin; $\gamma$-globulin did not inhibit up to $5 \mathrm{mg} . / \mathrm{ml}$, the highest concentration tested.

Table 3. Effect of lipids on subtilysin haemolysis of rabbit red cells

$\begin{array}{lc} & \begin{array}{c}\text { Concentration required } \\ \text { to inhibit two-thirds of } \\ \text { test amount of } \\ \text { subtilysin } \\ (\mu \mathrm{g} . / \mathrm{ml} .)\end{array} \\ \text { Phosphatidylcholine (egg) } & 4 \\ \text { Phosphatidylcholine (beef) } & 5 \\ \text { Phosphatidylinositol } & 6 \\ \text { Phosphatidylserine (brain) } & 100 \\ \text { Phosphatidylserine (plant) } & 70 \\ \text { Phosphatidylethanolamine (plant) } & 500 \\ \text { Diphosphatidylglycerol (beef heart) } & 500 \\ \text { Phosphatidic acid } & 10 \\ \text { Sphingomyelin (beef heart) } & 5 \\ \text { Cerebrosides (beef brain) } & 400 \\ \text { Cholesterol } & 500\end{array}$

Inhibition of haemolysis by lipids. The foregoing results suggested that lipids may play an important role in inhibition of lysis by serum. A variety of lipids suspended or dissolved in $0.85 \%(\mathrm{w} / \mathrm{v}) \mathrm{NaCl}$ at $\mathrm{I} \mathrm{mg}$./ml. were tested for inhibition of lysis by adding decreasing amounts to 3 haemolysin units of subtilysin. The conditions were the same as those used for testing inhibition by serum and serum fractions. To improve dispersion, most of the preparations were briefly treated by sonication before testing. The results (Table 3) show that low concentrations of several phosphatides, most notably phosphatidylcholine, phosphatidylinositol, phosphatidic acid and sphingomyelin, inhibited subtilysin haemolysis. A high concentration of cerebrosides was required to produce inhibition; cholesterol did not inhibit at all.

\section{Bacteriolytic and antibiotic activity}

Protoplasts and spheroplasts were prepared from a variety of bacteria according to methods used earlier (Bernheimer \& Schwartz, 1965; Bernheimer, 1966). Extinctions of suspensions of protoplasts and spheroplasts were recorded continuously with a Cary spectrophotometer at $500 \mathrm{~nm}$. for $30 \mathrm{~min}$. at about $20^{\circ}$, with or without subtilysin. Substantial decrease in extinction was interpreted as evidence of lysis; estimates of lytic activity were made from the quantity of subtilysin needed to cause half-maximum decrease in extinction. The results (Table 4) show that protoplasts of a variety of Gram-positive bacteria were lysed, whereas among Gram-negative bacteria spheroplasts of Escherichia coli were lysed while those of Vibrio comma were not. The concentration of subtilysin required to disrupt protoplasts of the more sensitive bacterial species was about the same as that needed to lyse rabbit red cells.

Antibiotic activity was assayed by the tube dilution method. Doubling dilutions of 
subtilysin were prepared in trypticase soy broth for all organisms with the exception of Streptococcus pyogenes; for the streptococcus, Todd Hewitt broth was used. Each assay tube containing subtilysin in $2 \mathrm{ml}$. sterile broth was inoculated with a $5 \mathrm{~mm}$. loopful of a $20 \mathrm{hr}$ culture of test bacterium, and incubated at $37^{\circ}$ for 3 days. Growth was estimated visually and scored at o to $4+$. Growth of $S$. pyogenes was completely inhibited by subtilysin in a concentration of 0.6 haemolysin units $/ \mathrm{ml}$. (about $6 \mu \mathrm{g}$. $/ \mathrm{ml}$.). Corynebacterium diphtheriae and Bacillus megaterium were completely inhibited by I and 2 haemolysin units/ml,, respectively. Sarcina lutea and Micrococcus lysodeikticus were partially inhibited by 15 haemolysin units/ml., whereas Escherichia coli was not affected by this concentration, the highest tested. Similar results were obtained in experiments with subtilysin-containing paper discs on agar plates, but $S$. lutea was more sensitive and $B$. megaterium less sensitive than would have been predicted from the data derived from the broth assays. No inhibition of growth was obtained with Staphylococcus aureus, Gaffkya tetragena, Streptococcus faecalis, Bacillus cereus, B. subtilis, Lactobacillus casei, E. coli or Pseudomonas aeruginosa.

Table 4. Lysis of bacterial protoplasts and spheroplasts by subtilysin

$$
\begin{gathered}
\text { Approximate concentration } \\
\text { producing half-maximal } \\
\text { reduction in turbidity } \\
(\mu \mathrm{g} . / \mathrm{ml} .)
\end{gathered}
$$

Bacillus megaterium кM protoplasts (lysozyme)

Streptococcus pyogenes $\mathrm{C} 203 \mathrm{~s}$ protoplasts (phage-associated enzyme)

S. pyogenes GL 8 protoplasts (phage-associated enzyme)

Escherichia coli $\mathrm{K} 12$ spheroplasts (lysozyme)

$E$. coli $\mathrm{K} 12$ spheroplasts (penicillin)

S. faecalis ATCC 9790 protoplasts (lysozyme)

Sarcina lutea protoplasts (lysozyme)

Vibrio comma spheroplasts (penicillin)

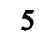

5

7

10

IO

II

20

65

$\mathrm{N}^{*}$

* $\mathrm{N}$ means no lysis at $100 \mu \mathrm{g} . / \mathrm{ml}$.

\section{DISCUSSION}

The agent responsible for the haemolytic activity of Bacillus subtilis was present in cultures in relatively large amounts, and it seems likely that it would have been seen before. The haemolytic moeity examined by Williams (1957) was probably subtilysin, and the properties of a substance termed serolysin by Aida, Koyama \& Uemura (1964) suggest that it may be the same as the material we have studied. While the present work was in progress there came to our attention a paper by Arima, Kakinuma \& Tamura (1968) describing the isolation and characterization of a $B$. subtilis product that is a potent inhibitor of blood clotting. The clotting inhibitor, named surfactin, is a peptidelipid whose structure has been elucidated (Kakinuma et al. 1969a,b,c) as

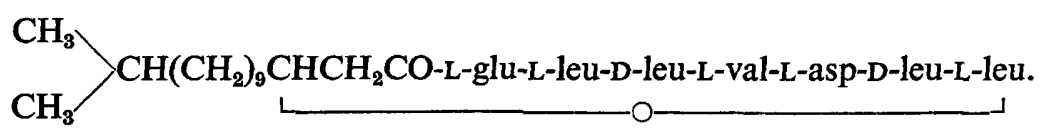

Comparison of the properties of subtilysin and surfactin showed that they possess many features in common, not least being a peptide of the same amino acid composi- 
tion. A sample of surfactin supplied by Dr Kakinuma was found to have the same specific haemolytic activity for rabbit red cells as subtilysin. Moreover, the two substances showed a similar time-course of haemolysis (Fig. 4). A sample of subtilysin sent to Tokyo was examined for inhibition of the thrombin-fibrinogen reaction by Dr Kakinuma who provided the plot reproduced as Fig. 5. The clotting system consisted of $0.5 \%$ fibrinogen (Armour Bovine Fraction I containing about $30 \%$ clottable protein), subtilysin as indicated, thrombin 5 units $/ \mathrm{ml}$. and $0.01 \mathrm{M}$-tris $+0.073 \mathrm{M}-\mathrm{NaCl}$ (pH 7.4). Clotting time, the interval from thrombin addition to clot formation, was measured at $37^{\circ}$. The combined results left no doubt about the identity of subtilysin with surfactin; it would therefore seem appropriate to abandon the former designation.

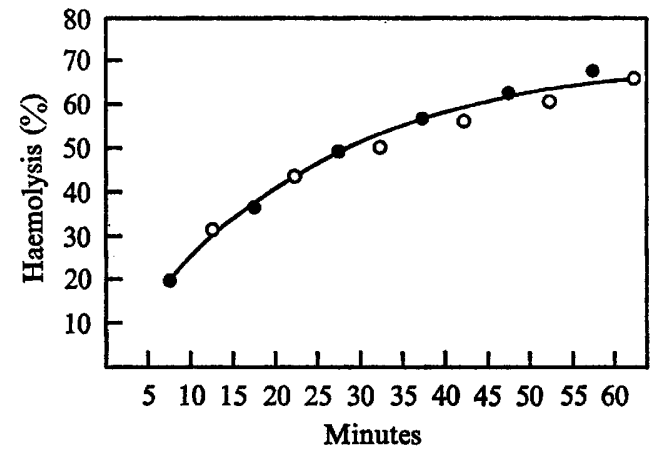

Fig. 4

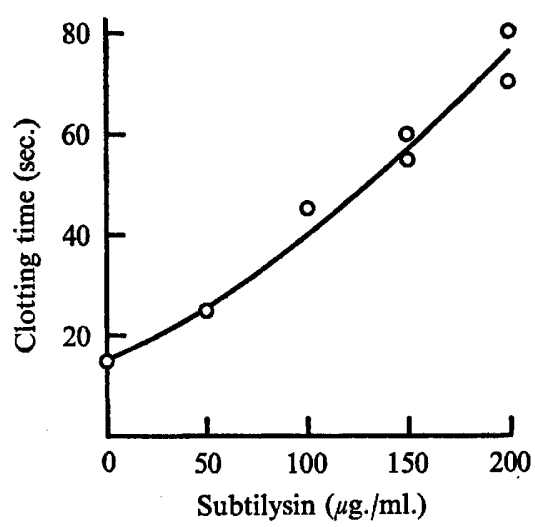

Fig. 5

Fig. 4. Course of haemolysis by subtilysin, $9 \mu \mathrm{g} . / \mathrm{ml}$. (open circles), and by surfactin, $10 \mu \mathrm{g} . / \mathrm{ml}$. (solid circles).

Fig. 5. Inhibition of clotting by subtilysin.

Surfactin possesses certain features common to at least two other agents of bacterial origin: staphylococcal $\delta$-toxin and streptolysin S. As extracellular products of growth all are lytic, not only for mammalian erythrocytes but also for protoplasts and spheroplasts of certain bacteria. The lytic effects of all three are inhibited by phospholipids, and presumably phospholipids are the constituents of plasma membranes with which they interact to produce cell lysis. The biological activity of surfactin appears to depend upon the amphipathic nature of the molecule. One can speculate that the same may prove true of staphylococcal $\delta$-toxin. It is noteworthy that surfactin and streptolysin $\mathrm{S}$ both contain peptides: neither of them is antigenic nor is $\delta$-toxin.

The authors acknowledge with thanks the help of Dr A. Kreger who did the assays of antibiotic activity and the tests of sensitivity of different red cell species. To Mr D. Green and Dr B. L. Van Duuren we are indebted for infrared absorption data. We thank Mr C. Harman for operating the amino acid analyser and Mr F. Zaboretsky for making the ultracentrifugal analysis. This work was supported in part by a grant (AI-02874) from the National Institute of Allergy and Infectious Diseases of the U.S. Public Health Service, by a grant from the Life Insurance Medical Research Fund, and by Public Health Service Research Career Program Award 5K6-AI-14, 98. 


\section{REFERENCES}

AIDA, T., Koyama, Y. \& Uemura, T. (1964). Serolysin produced by Bacillus subtilis 427-4. Chemical Abstracts 3458.

ANDREws, P. (1964). Estimation of the molecular weights of proteins by Sephadex gel-filtration. Biochemical Journal gr, 222-233.

Arima, K., Kakinuma, A. \& TAmURA, G. (I968). Surfactin, a crystalline peptidelipid surfactant produced by Bacillus subtilis: isolation, characterization and its inhibition of fibrin clot formation. Biochemical and Biophysical Research Communications 31, 488-494.

BERNHEImer, A. W. (1966). Disruption of wall-less bacteria by streptococcal and staphylococcal toxins. Journal of Bacteriology 9x, 1677-1680.

Bernteimer, A. W. (1970). In Microbial Toxins, vol. I, ch. 5. Edited by S. J. Ajl, T. C. Montie and S. Kadis. New York: Academic Press. (In the Press.)

BERNHEIMER, A. W. \& GRUSHOFF, P. (1967). Cereolysin: production, purification and partial characterization. Journal of General Microbiology 46, I43-150.

Bernheimer, A. W. \& Schwartz, L. L. (1963). Isolation and composition of staphylococcal alpha toxin. Journal of General Microbiology 30, 455-468.

Bernheimer, A. W. \& Schwartz, L. L. (I965). Lysis of bacterial protoplasts and spheroplasts by staphylococcal $\alpha$-toxin and streptolysin S. Journal of Bacteriology 89, I387-1392.

Blackburn, S. (1968). Amino Acid Determination. New York: Marcel Dekker, Inc.

Büsing, K. H. (1950). Notizen über das Subtilis-Haemolysin. Archiv für Hygiene, Berlin r33, 63-68.

Colowick, S. P. \& Kaplan, N. O. (1957). Anthrone reaction. Methods in Enzymology 3, 84-85.

Kakinuma, A., Hori, M., Isono, M., TAmura, G. \& Arima, K. (1969a). Determination of amino acid sequence in surfactin, a crystalline peptidelipid surfactant produced by Bacillus subtilis. Agricultural and Biological Chemistry 33, 971-972.

Kakinuma, A., Hori, M., Sugino, H., Yoshida, I., Isono, M., Tamura, G. \& Arima, K. (1969b). Determination of the location of lactone ring in surfactin. Agricultural and Biological Chemistry $33,1523-1524$.

Kakinuma, A., Sugno, H., Isono, M., Tamura, G. \& Arima, K. (1969c). Determination of fatty acid in surfactin and elucidation of the total structure of surfactin. Agricultural and Biological Chemistry 33, 973-976.

KNIGHT, B. C. J. G. \& ProOM, H. (1950). A comparative survey of the nutrition and physiology of mesophilic species in the genus Bacillus. Journal of General Microbiology 4, 508-538.

Lohmann, K. \& Jendrassik, L. (I926). Kolorimetrische Phosphorsäurebestimmungen in Muskelextrakt. Biochemische Zeitschrift 178, 419-426.

Lowry, O. H., Rosebrough, N. J., FARR, A. L. \& Randall, R. J. (I95I). Protein measurement with the Folin phenol reagent. Journal of Biological Chemistry r93, 265-275.

Williams, G. R. (1957). Haemolytic material from aerobic sporing bacilli. Journal of General Microbiology 16, 16-21. 